\title{
Gene Amplification
}

National Cancer Institute

\section{Source}

National Cancer Institute. Gene Amplification. NCI Thesaurus. Code C16605.

Any DNA sequence rearrang ement that results in the gain of one or more copies of a DNA segment that contains at least one gene. 